\title{
INTEGRATION OF INTERACTIVE MEDIA INTO FOREIGN LANGUAGE LEARNING TO SUPPORT EFFICIENCY OF STUDY PROCESS
}

\author{
Laima Kuprienè \\ Vaida Žegunienė \\ Klaipeda University, Lithuania
}

\begin{abstract}
Contemporary society is actively engaged into technology innovations due to their multi-purposeful usage for personal, professional and educational reasons. Many new terms defining information communication technologies appear but the paper focuses on the interactive media, which may be considered as an integral part of the phenomenon. It is aimed to analyze and discuss the possibilities of integration of interactive media into language learning process to support the efficiency of the study process taking into consideration the needs and achievements of students. The lectures organized with traditional teaching material are getting old-fashioned gradually; therefore, new trends appear in the education process and technologies have to be successfully integrated by the teachers working in higher education institutions. Currently life pace is extremely fast, and rapid changes influence the life of young people who want to be well-educated and prepared for the further professional career. The research was organized to investigate whether the students of higher education institution demonstrate willingness to integrate interactive media into language learning process, i.e. students do not have to be passive users but actively apply and use interactive media in the learning process. Consequently, the teachers have to be familiar with the opportunities provided by the interactive media and acknowledge the necessity of its integration, but still some considerations and uncertainty exist. The methods used for the research are as follows: analysis of the scientific literature sources, content analysis, and questionnaires. Findings of the research are formulated after analysis of the collected data and they revealed the capabilities of the students to use interactive media and perception of the importance and usefulness of such measures. Majority of teachers demonstrate conservative attitude towards innovations and implementation of modern teaching/learning methods, but the situation will be improved putting the efforts in order to seek positive learning outcomes and modernize the study process.
\end{abstract}

Keywords: media, interactive media, innovative teaching/learning methods, foreign language teaching.

\section{Introduction}

In the current situation of rapidly developing technologies majority of citizens are more actively engaged into the network structure of the Internet. 
Variety of casual situations has been transferred to the virtual medium - from the reading of books to the realization of ideas. Despite that, it still remains unclear whether the expansion of interactive media is stimulated by modern technological decisions and self-realization of human-beings, or newly established networks aim to involve new users just for reasons of communication and innovation. Stoll (1995) notes that a human-being is not able to survive in the "dessert" of the Internet without changes in own nature. Media, which is a basis for the modern process of communication, transforms the construction of human thoughts, their formulation and the methods of communication. A human-being might be mistaken by thinking that he/she has entire control over any computer in the world; but unfortunately, it is very difficult to conceive the real essence and possible dangers of a computer usage, because devices constantly reprogram users, transform peculiarities of communication, and even arranges casual life activities (O'Keeffe and Clarke-Pearson, 2011). In 2006 the magazine "TIME" elected a person of the year "You", who is any person sitting in from of a computer screen and surfing the Internet nearly in every destination of the world. A reviewer Grossmann (2006) asked a rhetorical question on the essence of "You". According to him "You" is referred to a person who sits with a personal computer after a long working day, and instead of watching television programme he/she creates a movie about own life adventures or writes articles in own blog, searches for other virtual "You" aiming to form communities, share information, generate business ideas; consequently, that leads to virtual deformation of life. As Mwila (2015) noted virtual communication can diminish communication barriers and bring positive changes in society, on contrary that unlimited usage of technology can lead to addiction, violence and security issues.

Relevance and topicality of a study problem. Contemporary society is significantly engaged into usage of interactive media. This sphere has been analyzed implementing interdisciplinary researches by the specialists of various fields as sociologists, psychologists, linguists, information specialists and economists; Meyrowitz (1986) started to analyze media interaction with social behaviour, the impact of information technology on genders, appearance of new social roles and behavioural patterns, changes in environment. Valenzuela (2009) presents significant survey, and its data reveals students' attitude towards usage of media. Challenges and opportunities provided by interactive media are analyzed by Kaplan (2010). The author presents integral parts of common phenomenon "social media" and reviews frequency of usage taking into account the target audience - the youth. Lithuanian researchers pay attention to the particular aspects of virtual communication and interactive media application, for instance, peculiarities of e-language (Ryklienè, 2000), virtual expressions of community (Drevel, 2009), social networking (Rutkauskienè and Gudonienè, 2010), establishing of identity (Savicka, 2011), political communication in social 
networks (Šuminas, 2009), economical benefits (Urniežiūtè, 2014). The application of interactive media into educational process, analysis of innovative teaching/learning methods, their combination with traditional methods, reviewing of application of computer technologies on the foreign language learning (Žegunienè et. al., 2014, Jankauskienè et. al., 2013, Leonavičienė and Salienė, 2013). Reviewing the foregoing, topicality of the problem analyzed in the paper is formulated as follows: integration of interactive media into teaching/learning process to support efficiency of study process needs further research.

Study problem may be formulated by asking a question "Why is not interactive media integrated into the process of foreign language learning?" It is considered as an extremely popular and attractive activity in the daily life (public or private) of almost each individual, but it is not positively evaluated as an educational tool.

Object of research - integration of interactive media into the foreign language learning.

Aim of research - to investigate the perception and attitude towards interactive media integration into the foreign language learning in order to support the efficiency of the study process.

\section{Goals of research:}

- To provide the basic characteristics of interactive media and peculiarities of its integration and usage to support the efficiency of the study process;

- To analyze the attitude of students towards learning with integrated interactive media;

- To reveal the attitude of teachers towards integration of interactive media into foreign language study process.

Methods: analysis of the scientific literature sources and generalization, content analysis and survey.

\section{Interactive media: situation in the European context}

The term "interactive media" was originated at the end of the $20^{\text {th }}$ century. As England and Finney (2002/2011) define "It is the integration of digital media including combinations of electronic text, graphics, moving images, and sound, into a structured digital computerized environment that allows people to interact with the data for appropriate purposes." Many disputes arise due to the classification of interactive media and its integral components, which are supplemented with new ones constantly. Generalizing the analysis of various authors Bates (1992), Wartella et.al (2000), Anderson (2011), Jurkevičiené (2012), Siudikienè (2013) the basic characteristics of interactive media might be 
as follows: interactivity, communication, free access, divergence, flexibility, attractiveness, multi-formats of information and interactive active participation. Media provides people with assistance when they aim to exchange information and ideas on particular issues, create communities. Furthermore, the information is exchanged using different channels and methods such as written method of communication (blogs, comment, and chat rooms), visual information (short movies, games), graphical information (photos, pictures), audio (music files) and etc.

Variety of governmental documents of the European level demonstrates concern regarding interactive media usage and incorporation into educational systems and study process. Communication and media experts do not demonstrate positive attitude towards existing situation and emphasize necessity to make some improvements. Application of interactive media and promotion of media literacy is emphasized in Grunwald Declaration on Media Education (1982), UNESCO Paris Agenda (2007), Framework and Plan of Action for the Global Alliance for partnerships on media and information literacy promoting media and information literacy as a means to open and inclusive development (2013), Strategic Guidelines and Policy of Media and Information Literacy (2013), Global Map of Media Education Policy: Visions, Programmes and Challenges (2009). Situation in Lithuania is gradually improved due to the reaction and primary actions implemented by the secondary education schools and gymnasiums. Extracurriculum activities are organized, where students may get familiar with information communication technologies, and peculiarities of interactive communication tools. Situation in the Lithuanian higher education institutions is still slightly uncomplimentary and progress is negligible.

\section{Interactive media: new opportunities for foreign language learning}

Having reviewed the European documents where usage of interactive media is emphasized, and having discussed the basic characteristics of interactive media, interactive media is significantly beneficial for the foreign language teaching/learning process. If interactive media was chosen for the study process, a student would be able to select from variety of learning methods (educational games, websites, chat rooms, forums, internet games, social networks etc.). Communication among students could be organized in more convenient and attractive manner. The study process can be organized outside usual teaching/learning environment, communication between a teacher and a student would not be limited by time, availability and place. Interactive media can be a platform that will be used as an educational environment for exchange of methodological aids, accumulation of multi-format information and links to the scientific sources used for the lessons and independent studies. Specialized 
websites contain many useful links to the educational websites, which help to study any foreign language; forums, which are used for communication among native and non-native speakers; communities of teachers-volunteers who are engaged into online teaching.

As Leonavičienè and Salienè (2013) noted, language learning is referred to as an active process of foreign language skills formation and it has to be uninterrupted. The successful and efficient language teaching/learning process needs the combination of theory and practice, so environment of study process plays a vital role, and actually, that is a duty of a teacher to provide students with modern and interactive possibilities to support their positive achievements in foreign language learning; for instance, course books may be partially replaced with innovative methods, such as interactive media that comprises websites of newspapers or magazines, internet clubs, websites of business companies, forums, films etc.

Interactive media with its peculiarities becomes efficient tool for choosing appropriate level of language learning taking into consideration peculiarities of learners. Respectively, a student is able to select topics and activities, which may fulfill the needs and wishes of a young modern person. Reviewing possibilities provided by interactive media the teaching/learning process becomes more individualized, the material may be adapted in more flexible manner to meet requirements of various learners; the entire study process is continuously transformed in order to achieve positive learning outcomes. Furthermore, interactive media may be referred to both as a methodological aid and a platform for submitting students' assignments. There is a possibility to create a virtual class, club or blog for students and teachers, where students could upload their visual, written, audio material, presentations, papers, essays etc., and their submitted assignments can be assessed by peers and teachers. (Wilksch et.al 2006)

According to the TNS survey (2015) majority of respondents of $15-30$ years old is active users of the Internet (15-19 years old - 99\%, $20-29$ years old $98 \%$ ). Currently the users of the Internet are members of at least two social networks and platforms. The development of new networks is still in process, because various networks are focused on the basic needs of users: communication, entertainment, receiving and managing of information and its administration. The huge group of users is interested in search systems and e-publications.

In generalization, a basic feature of interactive media is interactivity, because media may be developed by everybody and the content of information depends on the objects who are involved in the process of information share and exchange.

Students are extremely active users of interactive media. They acknowledge provided possibilities and know how to get benefit of interactive media usage. The virtual environment is attractive in educational perspective. Therefore teachers have to be ready to integrate interactive media into study process, 
Laima Kuprienè, Vaida Žegunienè. Integration of Interactive Media into Foreign Language Learning to Support Efficiency of Study Process

because this innovative method stimulates study process, makes it efficient and modernized.

\section{Methodology of Research}

The research has been organized and performed in 5 Lithuanian higher education institutions in order to analyze the attitude of teachers and students towards the integration of interactive media into foreign language teaching/learning process. The research has been initiated in 2016. There were two target groups: foreign language teachers (52 respondents representing higher education institutions in Lithuania) and students, who study any foreign language (198 respondents from education institutions in Lithuania). The instrument of the research - a questionnaire form comprising 15 questions. Questions were formulated diagnostically aiming to investigate and analyze respondents' perception of interactive media and positive aspects of its integration into foreign language study process. The most relevant data has been interpreted and elucidated.

\section{Students' attitude towards the integration of interactive media}

The interviewed students were asked to indicate two types of interactive media, which they use at least 3 times a week. (Fig. 1)

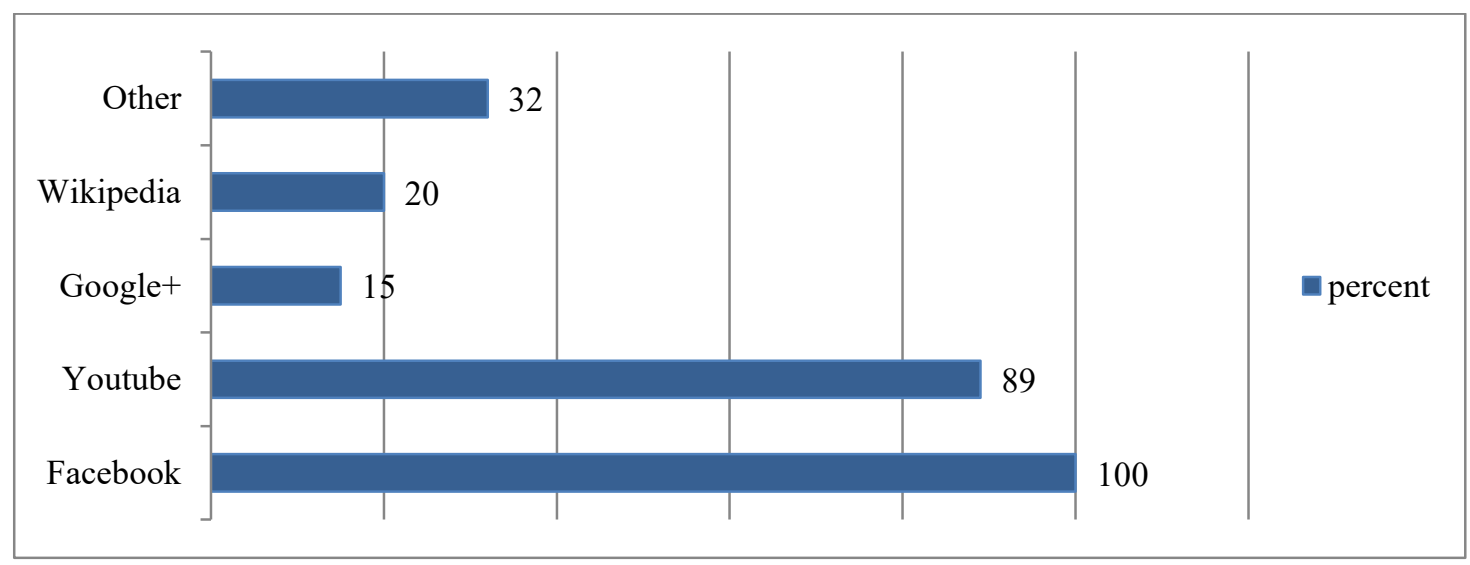

Figure 1 The most popular interactive media used by students

The illustrated data reveals the fact that all interviewed respondents $(100 \%)$ spend their time in the Facebook network, 89\% - in Youtube channel, 15\% - use Google+, respectively the smaller amount of respondents noted that they use Wikipedia encyclopedia occasionally. Beside the most frequently used media, the students mentioned website "Flikr, network for Russian speakers "VK", Lithuanian club for parents "supermama.lt". 
The analysis of the answers revealed that students perceive interactive media in a very narrow aspect. For instance, interactive media is indentified with the social networks as Facebook, Google+. Informational portals and databases (Wikipedia) have been mentioned just by five respondents. Additional integral parts of interactive media have not been mentioned by the respondents, such as blogs, wikis, video games, online newspapers, websites, forums, on-line platforms, etc. That leads to conclusion that foreign language teachers are very limited with the selection of interactive media parts and their integration into study process. It is obvious that basically English language is used for the communication and information in the Internet, consequently, the perfect educational opportunity to develop foreign language (English, German, French, Spanish, etc.) skills is missed.

Students' leisure activities related to the usage of interactive media are elucidated in Fig.2

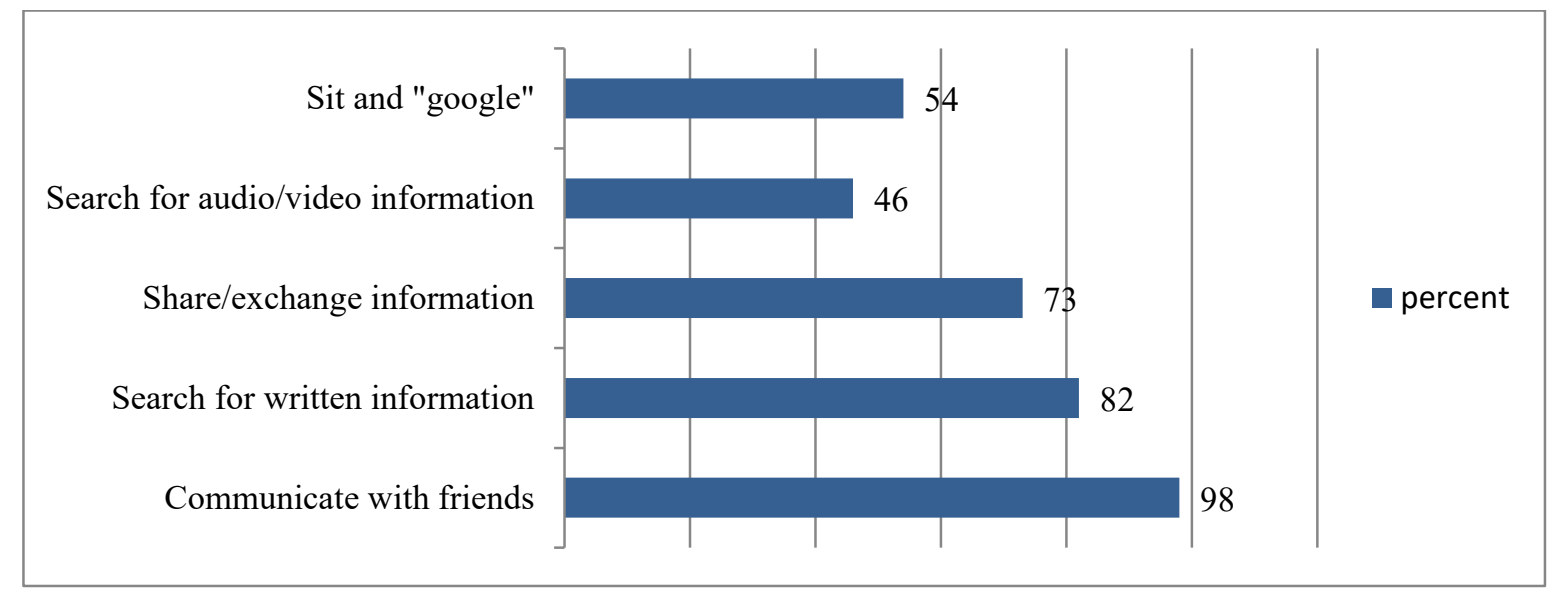

Figure 2 On-line activities performed by students

Majority of students $(98 \%)$ noted that interactive media helps them to communicate with friends, part of them (82\%) searches for written information (text, articles, essays, blogs etc.). More than half of the respondents (73\%) shares or exchanges information, useful links and websites with others; less respondents (46\%) search just for particular audio or video information. More than half (54\%) of the interviewed students indicated that the main activity is just sitting in front of a personal computer screen and "googling" for any information.

Acquired answers do not include option of the interactive media integration into the teaching/learning process. The activities mentioned by the respondents are related to the leisure time but not study process. The aim of interactive media usage is not educational but more personal. That leads to conclusion that both the teachers and students are not interested in usage of interactive media while teaching/learning foreign language. According to the data the basic characteristics 
of interactive media (communication, free access, active participation of the participants (students and teachers), exchanging of information, innovative teaching/learning methods) are not interrelated to success and efficiency of the foreign language study process and high achievements.

Further, the students were asked to express their opinion whether interactive media has to be integrated into the process of foreign language learning. (Fig. 3)

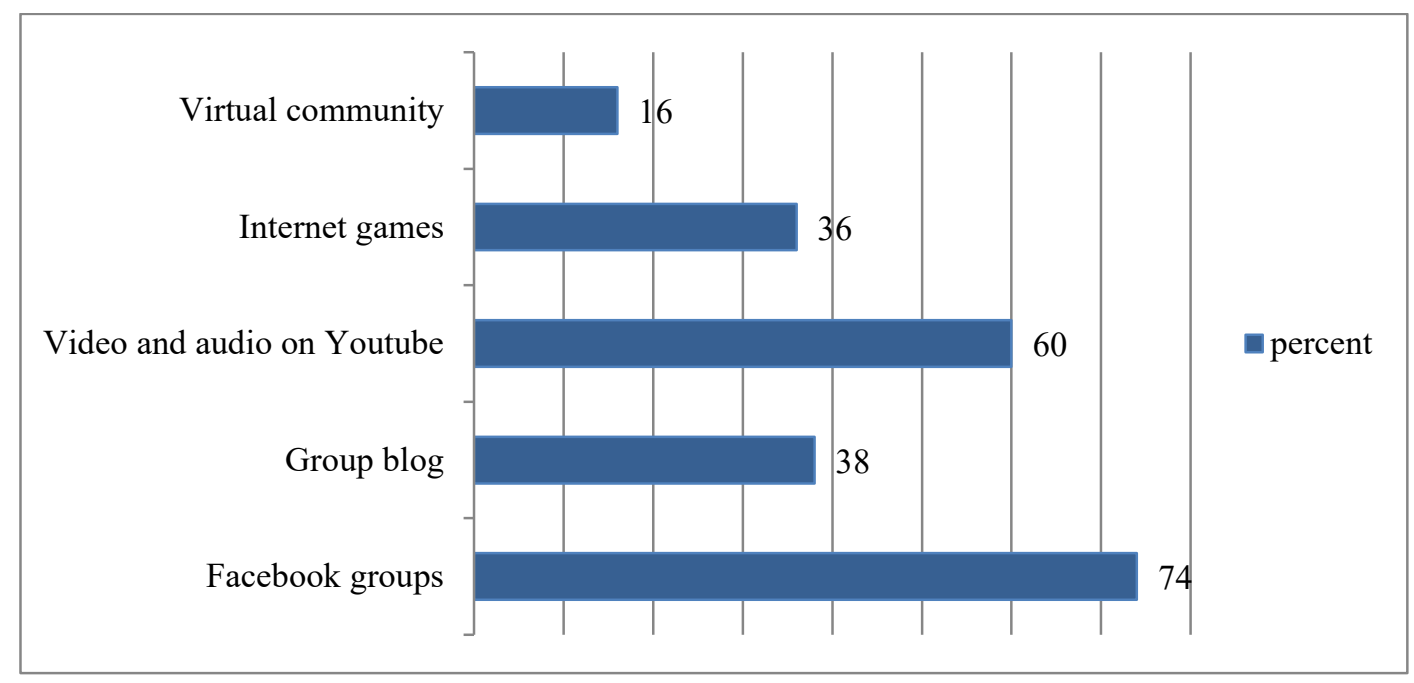

Figure 3 Integration of interactive media into foreign language study process

As the research data shows, majority of students (74\%) noted that the study process can be more efficient and attractive integrating interactive media into the foreign language study process due to possibility to download their assignments in audio/video formats to websites or blogs, to comment on peers papers and submitted tasks. $74 \%$ of respondents suggested to search for information creating Facebook group, 38\% proposed to create a blog, 60\% mentioned usage of Youtube channel, $36 \%$ offered to play internet games for educational purposes, $16 \%$ thinks that development of virtual communities may modernize foreign language learning/teaching process.

Analysis of data revealed the positive attitude of students towards innovative and non-traditional methods of foreign language learning. Respondents showed willingness to integrate interactive media into the foreign language learning to support the efficiency of study process because multi-format content of the Internet sources allows efficient exchange of information between teachers and students for educational purposes. Modern teaching methods make study process available for each student with own personal characteristics. Usage of interactive media satisfies students' wishes to be independent, to use visual, audio or graphical formats for enhancement of their foreign language skills. On-line 
simulations, games, quizzes make study process more entertaining, what reduces the level of stress and creates autonomy for every student.

\section{Teachers' attitude towards the integration of interactive media}

Foreign language teachers have been asked to select from a list of the Internet sources used for the foreign language teaching. (Fig. 4)

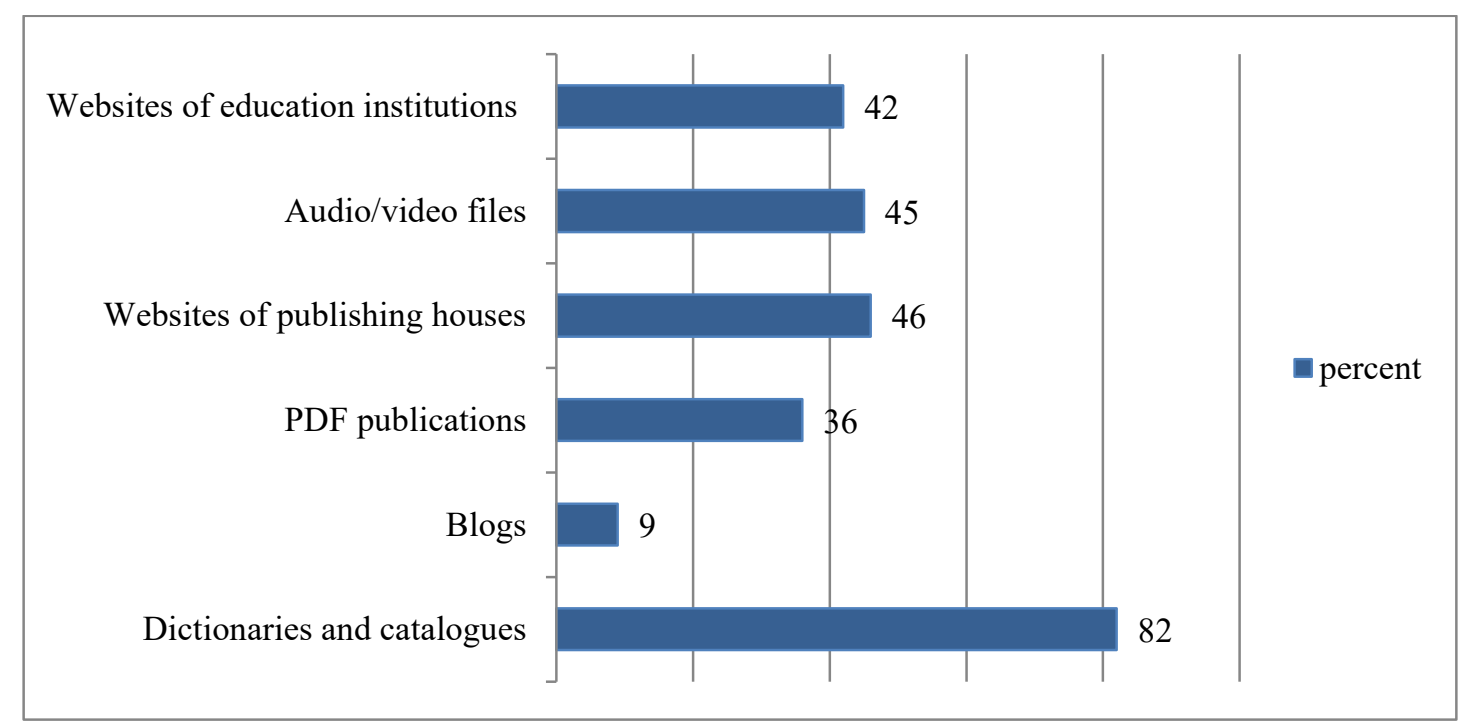

Figure 4 Internet sources used by teachers for foreign language teaching

Primary source for foreign language teaching indicated by teachers (82\%) was dictionaries and catalogues, significantly smaller group of respondents $(9 \%)$ mentioned personal blogs. Full-text PDF books and articles are used by $36 \%$ of foreign language teachers. Almost third of the respondents $(45 \%)$ search for audio/video files, approximately the same number of respondents (46\%) uses supplementary material for foreign language teaching provided by the publishing houses, and $42 \%$ search for information in the websites of education institutions.

As presented data shows teachers use the sources of interactive media preparing material for the lessons, but these sources and website links are not included into a list of recommended literature sources and not recommended to use for foreign language learning. The respondents indicated different sources of interactive media compared to the students. Students are familiar with more integral parts of interactive media and acknowledge advantage provided by social networks (Facebook, Google+), forums, chat rooms, on-line groups. They have mentioned on-line encyclopedias, Youtube channel, virtual communities, blogs used for their daily activities and some of these measures can be integrated into foreign language study process. 
Despite the fact that teachers demonstrate positive attitude towards interactive media using it for lesson preparation, teachers do not tend to integrate interactive media into the foreign language lessons and give students interactive tasks. (Fig. 5).

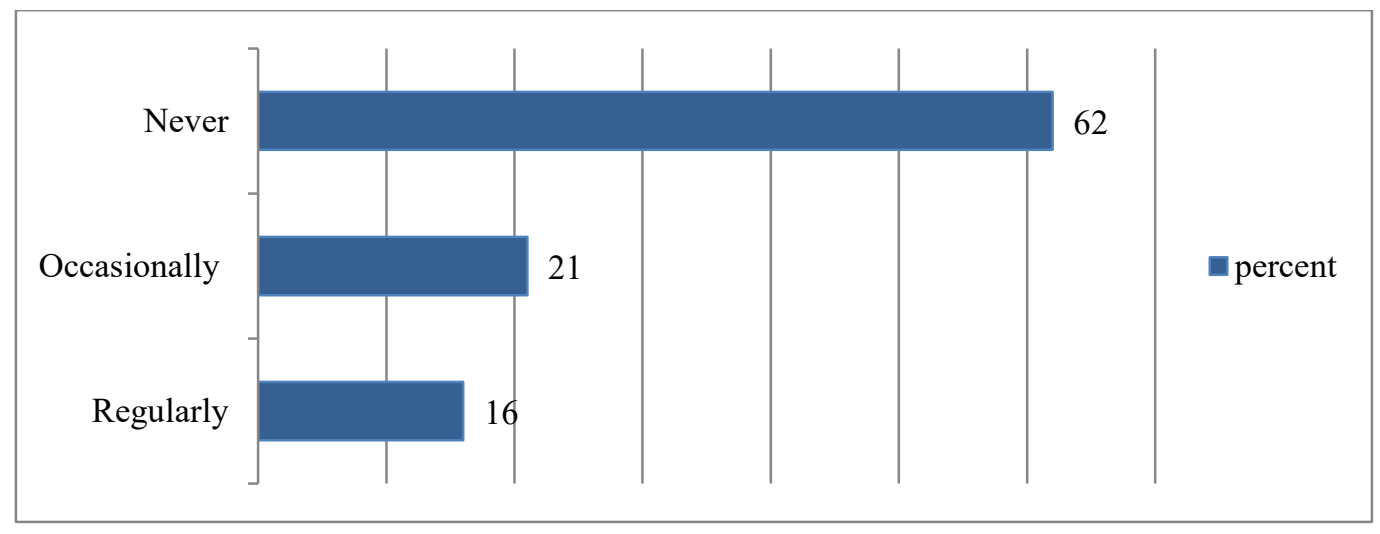

Figure 5 Integration of interactive media into foreign language learning

Just $16 \%$ of teachers assign interactive tasks for students during foreign language lessons. Occasionally such tasks are given by $21 \%$ of the respondents and majority of interviewed teachers $(62 \%)$ do not show willingness to integrate interactive media into foreign language study process. Having analyzed teachers' attitude and responses it is assumed that teachers demonstrated negative attitude due to several factors, such as interactive tasks checking and assessment procedures, and there is some uncertainty about fairness of students. Interactive media still is considered to as a challenge for foreign language teaching/learning. Teachers' duty and responsibility is to get familiar with modern technologies and their educational opportunities. Modern (communicative, situational/natural context-oriented methods, community language learning methods innovative technologies, and interactive activities) and traditional teaching/learning methods (teacher-oriented, grammar translation method, aural-oral and oral-audio methods, reading methods) have to be combined in order to make study process more efficient.

\section{Conclusions}

Interactive media can be characterized mentioning the basic characteristics such as interactivity, communication, free access, divergence, flexibility, attractiveness, multi-formats of information and interactive participation, availability to share and exchange multi-content and multi-format information in order to communicate efficiently, to create communities, to comment on published information and to express own personality. Almost each person of 
contemporary society can become an active user of interactive media. Updated information, various educational activities, different information sources provide users (teachers and students) with evidence that integration of interactive media supports efficiency of foreign language learning and teaching. The data of the research reveals that interactive media is used by both the teachers and students, but most cases of usage were not related with educational purposes.

On the research data basis the interviewed students are very active users of interactive media for their personal needs. Majority of the respondents are engaged into "googling" and communication with friends via Facebook or other social networks, in searching for information in various websites (Youtube), but mostly just for pleasure. On contrary, the respondents demonstrated willingness to have interactive media integrated into foreign language teaching/learning process. Educational platforms, blogs, forums, games and social networks have been mentioned as possibility to deepen foreign language skills in more innovative manner. Thus the study process may be more attractive and students could achieve positive learning outcomes if traditional methods will be combined with modern (communicative, situational/natural context-oriented methods, community language learning methods, innovative technologies, and interactive activities).

Comparing the answers of the both target groups, there is obvious evidence that interactive media is used differently. However, just few interviewed foreign language teachers use interactive media for educational purposes (preparation for lessons) but not as a virtual educational environment where students could take active participation. Majority of the respondents demonstrated negative attitude towards interactive media integration into foreign language learning process, and the situation has to be improved in the future.

\section{References}

Anderson, T. (2011). The theory and practice of online learning. Downloaded from: https://books.google.lt/books?hl=lt\&lr=\&id=RifNwzU3HR4C\&oi=fnd\&pg=PA167\&dq $=$ basic + characteristics + of + interactive + media\&ots $=$ SfdqIkNYqt\&sig $=\mathrm{Jd} 5$ tfcirvziY $\mathrm{xvw} 3 \mathrm{~m} \_$Z7YOyU-M\&redir_esc $=\mathrm{y} \# \mathrm{v}=$ onepage $\& \mathrm{q}=$ basic $\% 20$ characteristics $\% 20 \mathrm{of} \% 20$ interactive $\% 20$ media\& $\mathrm{f}=$ false

Bates, J. (1992). The Nature of Characters in Interactive Worlds and The Oz Project. Downloaded from: http://web.stanford.edu/dept/HPS/154/Workshop/The\%20Nature\% 20of\%20Characters\%20in\%20Interactive\%20Worlds\%20Bates\%20Joseph.pdf

Drevel, A. (2009). Virtualios bendruomenès išraiškos. Grupès ir aplinkos, 1. Downloaded from http://vddb.library.lt/fedora/get/LT-eLABa-0001:J.04 2009 ISSN_20294182.N_1.PG_177-197/DS.002.0.01.ARTIC

England, E., Finney E. (2002/2011). Interactive media - what's that? who's involved? ATSF White Paper-Interactive Media UK. Downloaded from: http://www.atsf.co.uk/ atsf/interactive_media.pdf 
Laima Kuprienè, Vaida Žeguniene. Integration of Interactive Media into Foreign Language Learning to Support Efficiency of Study Process

Jankauskienė, B. et.al (2013). Mokymo(si) metodu ịvairovė užsienio kalbu kompetencijos ugdymui. Downloaded from: https://ojs.kauko.lt/index.php/ssktipd/article/viewFile/ $418 / 421$

Jurkevičienè, J. (2012). Naujuju socialiniu mediju tipologija. Societal innovations for global growth. Downloaded from: https://www.mruni.eu/mru_lt_dokumentai/fakultetai/ socialines_informatikos_fakultetas/Konferencija/B_2012-12-26.pdf\#page=171

Grossmann, L. (2006). You - Yes, You - Are TIME's Person of the Year.Time Magazine. Downloaded from: http://content.time.com/time/magazine/article/0,9171,1570810, 00.html

Griunvaldo deklaracija (1982). Downloaded from: http://www.unesco.org/education/pdf/ MEDIA E.PDF

Kaplan, A. M. (2010). Users of the world, unite! The challenges and opportunities of Social Media. Business Horizons Volume 53, Issue 1, January-February 2010, Pages 59-68

Leonavičienè, A., Salienė, A. (2013). Inovatyvūs kalbų mokymo(si) metodai šiuolaikiniame ugdymo kontekste. Žmogus ir žodis, 15(1) Downloaded from: http://www.biblioteka. vpu.lt/zmogusirzodis/PDF/didaktinelingvistika/2013/leonav.sal139-143.pdf

Mediju ir informacinio raštingumo politikos bei strategijos gairès (2013). Downloaded from: http://unesdoc.unesco.org/images/0022/002256/225606e.pdf>

Mediju švietimo politikos pasaulio žemèlapis: vizijos, programos ir iššūkiai (2009). Downloaded from: http://www.unesco.org/new/en/communication-and-information/ resources/publications-and-communication-materials/publications/full-list/mappingmedia-education-policies-in-the-world-visions-programmes-and-challenges

Mwila, A.K. (2015). Positive and Negative Effects of Social Media on Society. Downloaded from: https://www.linkedin.com/pulse/positive-negative-effects-social-media-societyali-kingston

O'Keeffe, G. S., Clarke-Pearson, K. (2011). Clinical Report - The Impact of Social Media on Children, Adolescents, and Families. Downloaded from: http://pediatrics.aap publications.org/content/pediatrics/127/4/800.full.pdf

Pasaulinio partnerystès aljanso mediju ir informacinio raštingumo srityje programa bei veiksmu planas (2013). Downloaded from: http://www.unesco.org/new/ fileadmin/MULTIMEDIA/HQ/CI/CI/pdf/Events/gapmil_framework_and_plan_of_actio n.pdf

Ryklienè, A. (2000). Bendravimas internetu: kalbejjimas rašant. Darbai ir dienos, 24. Downloadedfromhttp://donelaitis.vdu.lt/publikacijos/rykliene.pdf

Rutkauskienè, D., Gudonienè, D. (2010). Socialinè tinklaveika: tendencijos ir iššūkiai. Downloaded from: http://www.upc.smm.lt/naujienos/web2/pdf/21_Rutkauskiene.pdf

Savicka, A. (2011). İtinklinta taptybè: vientisumo problema. Lietuvos kultūros tyrimai 1: Medijos, politika, vaizduote (50-60) . Vilnius: LKTI.

Siudikienè, D. (2013). Laisvalaikio medijų naudojimo ypatumai skirtingose Lietuvos auditorijos gyvenimo stilių grupèse. Informacijos mokslai. Downloaded from: http://www.journals.vu.lt/informacijos-mokslai/article/view/2068/1295

Stoll, C. (1995). Die Wüste Internet: Geisterfahrten auf der Datenautobahn. Frankfurt am Main: Fischer Verlag.

Šuminas, A. (2009). Politinè komunikacija socialinių tinklų svetainėse. Informacijos mokslai, 51. Downloaded from: http://www.vu.lt/leidyba/dokumentai/zurnalai/INFORMACIJOS \%20MOKSLAI/Informacijos\%20mokslai\%202009\%2051/24-36.pdf 
TNS (2015.) Metiné žiniasklaidos tyrimu apžvalga. TNS. Downloaded from: http://www.tns.lt/lt/top/paslaugos/ziniasklaidos-auditoriju-tyrimai/metine-ziniasklaidostyrimu-apzvalga/

UNESCO Paryžiaus darbotvarkè (2007). Downloaded from: http://www.unesco.lt/ images/stories/articles files/Paris_Agenda_2007.pdf>

Urniežiūté, N. (2014). Šeimos medicinos centrų komunikacijos su pacientais plètra socialiniuose tinkluose. Ekonomika ir vadyba: aktualijos ir perspektyvos, 1 (33). Downloaded from: http://vddb.library.lt/fedora/get/LT-eLABa-0001:J.04 2014 ISSN_1648-9098.N_1_33.PG_125-135/DS.002.0.01.ARTIC

Valenzuela, S. (2009). Is There Social Capital in a Social Network Site?: Facebook Use and College Students' Life Satisfaction, Trust, and Participation. Journal of computermediated communication. Volume 14, Issue 4. Downloaded from: http://onlinelibrary. wiley.com/doi/10.1111/j.1083-6101.2009.01474.x/full

Wartella, E. et al. (2000). Children and Interactive Media. A compendium of current research and directions for the future A Report to the Markle Foundation. Downloaded from: http://research.policyarchive.org/15470.pdf

Wilkisch, S. M., et.al. (2006). Impact of interactive school-based media literacy lessons for reducing internalization of media ideals in young adolescent girls and boys. Downloaded from: http://onlinelibrary.wiley.com/doi/10.1002/eat.20237/full

Žegunienè, V. et.al (2014). Inovatyvaus užsienio kalbu mokymo(si) proceso paradigma aukštojoje mokykloje. Downloaded from: http://old.vkk.lt/uploads/Konferencijos_CD_ 2014/data/files/ZegunieneParisauskieneJankauskiene.pdf 